\title{
MICROPALAEONTOLOGY NOTEBOOK Inter-shell casts of entactiniid radiolarians from the Devonian of SW China
}

\author{
HUI LUO ${ }^{1}$, JONATHAN C. AITCHISON ${ }^{1} \&$ YUJING WANG \\ ${ }^{1}$ Department of Earth Sciences, University of Hong Kong, Pokfulam Road, Hong Kong SAR, China \\ ${ }^{2}$ Nanjing Institute of Geology and Paleontology, Academia Sinica, Nanjing, China 210008
}

In the course of studies on Devonian radiolarian faunas from Nanning, Guangxi, SW China (Luo et al., 1997), numerous smooth siliceous microspheres (Fig. 1) are encountered together with abundant spherical entactiniid radiolarians. The present investigation reveals that these microspheres are siliceous casts formed through precipitation of silica between the medullary and cortical shells of entactiniid radiolarians. As these microspheres are commonly the most abundant particles encountered in some Devonian samples, an understanding of their origins is desirable.

Examined material is from two bedded chert samples collected from the upper part of the Tanhe Formation at Wuxiangling, $5 \mathrm{~km}$ SE of Nanning, Guangxi Province, SW China. Tanhe Formation consists of thin dark grey, brown grey cherty rock and cherty mudstone containing abundant radiolarians (entactiniids, ceratoikiscids and palaeoscenidiids) and tentaculitids. Based on zonation of tentaculitid faunas this formation is Lower to Middle Devonian (Upper Emsian - Lower Givetian) (Zhong et al., 1992; Kuang et al., 1996). A standard method (Pessagno \& Newport, 1972) for extraction of radiolarians from cherts using hydroflouric acid was applied.

Free microspheres are the most common individuals ( $\mathrm{Pl}$. 1, figs 1,8). All have smooth surfaces and possess some relatively larger holes or pores. Average microsphere diameter (20 specimens) is $92 \mu \mathrm{m}$. Hole shapes vary from three-bladed to round with spines rarely seen penetrating the microspheres (Pl. 1, figs 7, 10). A full range of material from microsphere-bearing entactiniids in which there are remnants of the original spongy radiolarian shells (P1. 1, figs 5-7,9) to solitary microspheres (P1. 1, figs 1,8 ) can be observed.

Microspheres are commonly preserved better than the original radiolarian shells and are the most common encountered particles in acid residues. The opaline silica skeletons of living radiolarians convert, during diagenesis, to quartz (De Wever et al., 1994). We suggest that the microspheres precipitated as quartzose inter-shell casts early during the diagenesis. Much of the original opaline silica of the original shells was possibly dissolved before conversion to quartz.
Some previously described radiolarian taxa may not actually be radiolarian shells rather they may be inter-shell casts such as those described herein. For example Cyclocarpus tubiformis described by Li \& Wang (1991) from the Liukiang Formation (Frasnian) in southeastern Guangxi Province has a spherical outer shell and no spines on its smooth surface. It is very similar in appearance to the microspheres described herein except that it has more pores. This taxon is probably a microsphere and, due to the nonpreservation of the original radiolarian shell, it is best regarded as a nomen nudum.

\section{ACKNOWLEDGEMENT}

Funding towards this research was provided by the Hong Kong Research Grants Council. We thank the two journal reviewers for their constructive comments.

\section{REFERENCES}

De Weaver, P. Azema, J. \& Fourcade, E. 1994. Radiolaires et radiolarites: production primaire, diagenese et paleogeographi. Bulletin Centres de Recherche, Exploration-Production Elf Aquitaine, 18: 315-379.

Kuang, G. D., Zhang, Z. W. Li, J. X. \& He, C. Y. 1996. Devonian and Carboniferous Stratigraphy, Sedimentary Facies and Paleontology of Guangxi Zhuang Autonomous Region. In: Hou, H. F. \& Zhou, J. S. (eds) 30th IGC Field Trip Guide. Geological Publishing House, Beijing, China. 1: T348.1-T348.32.

Li, Y. X. \& Wang, Y. J. 1991. Upper Devonian (Frasnian) Radiolarian Fauna from the Liukiang Formation, Eastern and Southeastern Guangxi. Acta Micropalaeontologica Sinica, 8: 395-404.

Luo, H. Wang, W. Y. \& Aitchison, J. C. 1997. Devonian radiolarian biostratigraphy of Guangxi Province, SW China. Abstracts, Interrad VIII, International Association of Radiolarian Paleontologists, Paris-Biervill, 8-13 September 1997. Laboratoire de Géologie du Museum, Paris, p. 90.

Pessagno, E. A., Jr. \& Newport, L. R. 1972. A technique for extracting Radiolaria from radiolarian cherts. Micropaleontology, 18: 231-234.

Zhong, K., Wu, Y., Yin, B., Liang, Y. L., Yao, Z. G. \& Peng. J. L. 1992. Devonian of Guangxi, Stratigraphy of Guangxi, China Part 1. China University of Geosciences Press, Beijing.

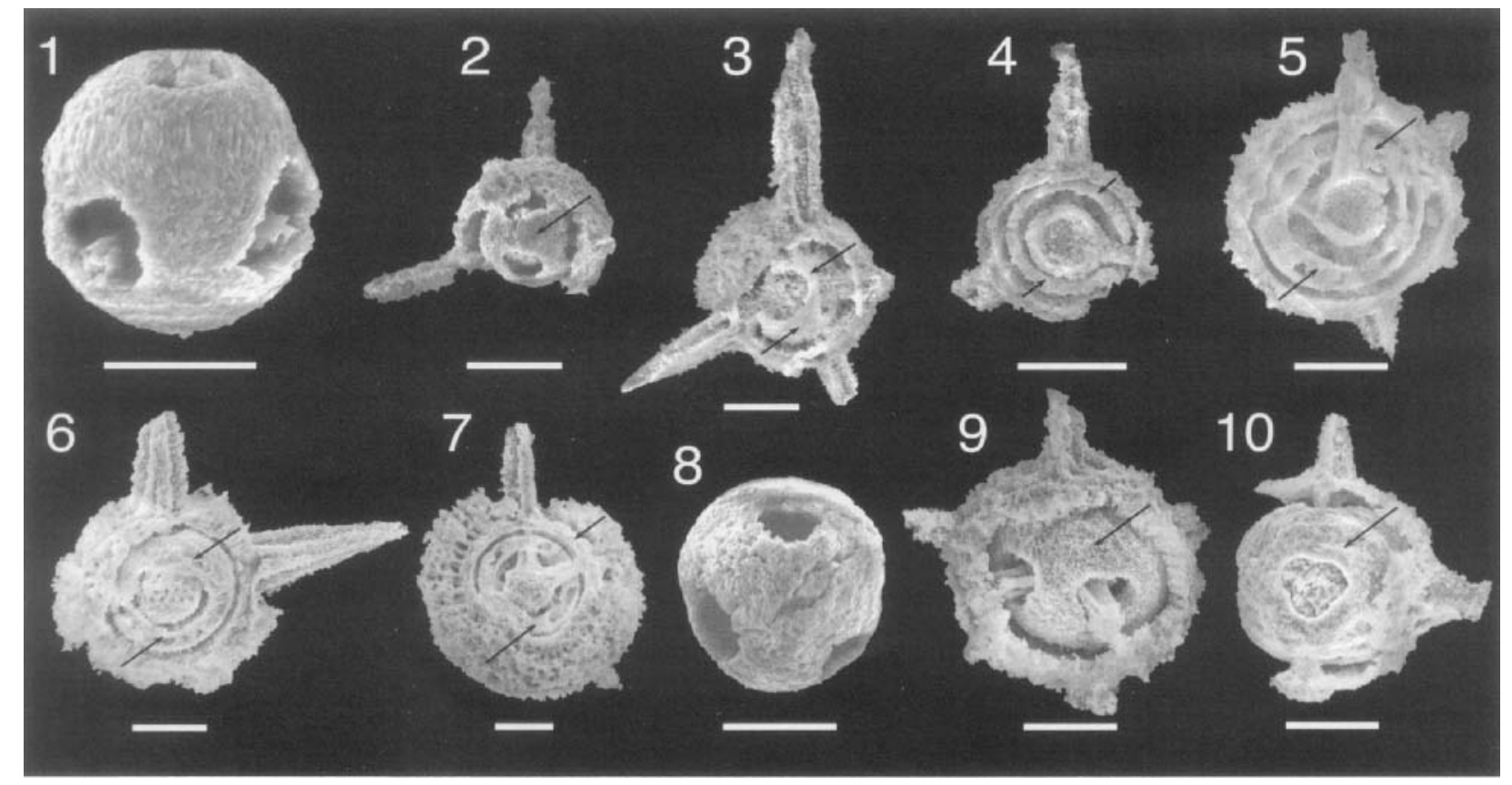

Explanation of Plate 1

Various stages of development of microspheres which represent inter-shell casts of entactiniid radiolarians. Specimens are housed at the Department of Earth Sciences, University of Hong Kong and were collected from the Lower to Middle Devonian of Guangxi, SW China. All scale bars are $50 \mu \mathrm{m}$. Figure 1 and 8 are microspheres. The presence of microspheres developed as inter-shell casts are indicated by arrows. Note that the microspheres typically have smooth surfaces in contrast to the porous spongy texture of the original radiolarian shells (e.g. fig. 7). 